\title{
THROUGH GERMAN EYES: AMATEUR PHOTOS AND TRANS-GENERATIONAL RENEGOTIATIONS OF THE HOLOCAUST
}

\author{
Kirril Shields
}

\section{Introduction}

In a trunk in my garage I have a sizable collection of photos gathered over a span of years. They are black and white images taken during Hitler's reign and each contains some reference to the Third Reich. Often they show uniformed men lounging with friends. Others reveal youth in Hitler Youth uniform, or a group of soldiers on military parade, and some contain little to no evidence of the Nazi party, with possibly just a flag in the background or a framed picture of Adolf Hitler on a wall. Others portray European Jews in their homes, in a shtetl, or in the camps, and a few have been taken by Allied soldiers as they moved across Europe from late-1944 to mid-1945. Similar in their production, each has been taken with a personal, hand-held camera. There are no press photos in the collection, no propaganda cigarette cards then common in Nazi Germany: the images are amateurish and often blurred, off-kilter, sometimes over-exposed, and the majority are mundane. They show (mostly) men and some women carrying out banal institutional and vocational activities: butchers, mechanics, cooks, soldiers, couriers, doctors, nurses and ditch diggers, to name just some. Their setting is slightly more adventurous, revealing a host of European regions-French beaches, the outskirts of Moscow, the very northern tip of Finland. I began collecting these images many years back when, on a five-month cycling trip through Europe, I kept coming across markets where stallholders sold individual photos, sometimes albums. I have since continued buying from online sources, as well as from the odd antique shop.

As mentioned, the majority of photos glimpse the day-to-day workings of the Reich from various working class perspectives. Contrastingly, though fewer in number, some images are at a remove from everyday settings. Not pictures of Hitler and his high-ranking entourage, but images whose innocuous look belies their more disturbing truth (although this might be true of any photos of the Third Reich). In this essay I look at two particular photos to interrogate photography as a memorialising link to the Holocaust, and by doing so discuss literal and representational modes of interacting with this past. The 
photos I explore represent particular types of German images. The first has been taken by a German and reveals individuals who are clearly victims of the regime. The second photo is an image taken by a member of the SS, showing his comrades enacting a similar role to that of the photographer. The gaze is similar, since both are from the viewpoint of perpetrators, yet the subject matter varies. Given their agenda and content, each is fraught with ethical and historiographical complexity. Individually and collectively, amateur German images are a problematic means of remembering the Holocaust, and the act of reinstating such images as insight into this history adds to the complexity. In questioning these photos' legitimacy, I explore Marianne Hirsch's idea of postmemory-inherited memories passed down the generations through, for example, the medium of the photo (to name one narrative form)-alongside Roland Barthes' discussion of the photo's punctum, those moments that arrest a viewer's gaze and reconfigure initial readings. I then discuss trans-generational shifts, assessing the photos' potency as legitimate representations of the Nazi regime.

\section{The photos}

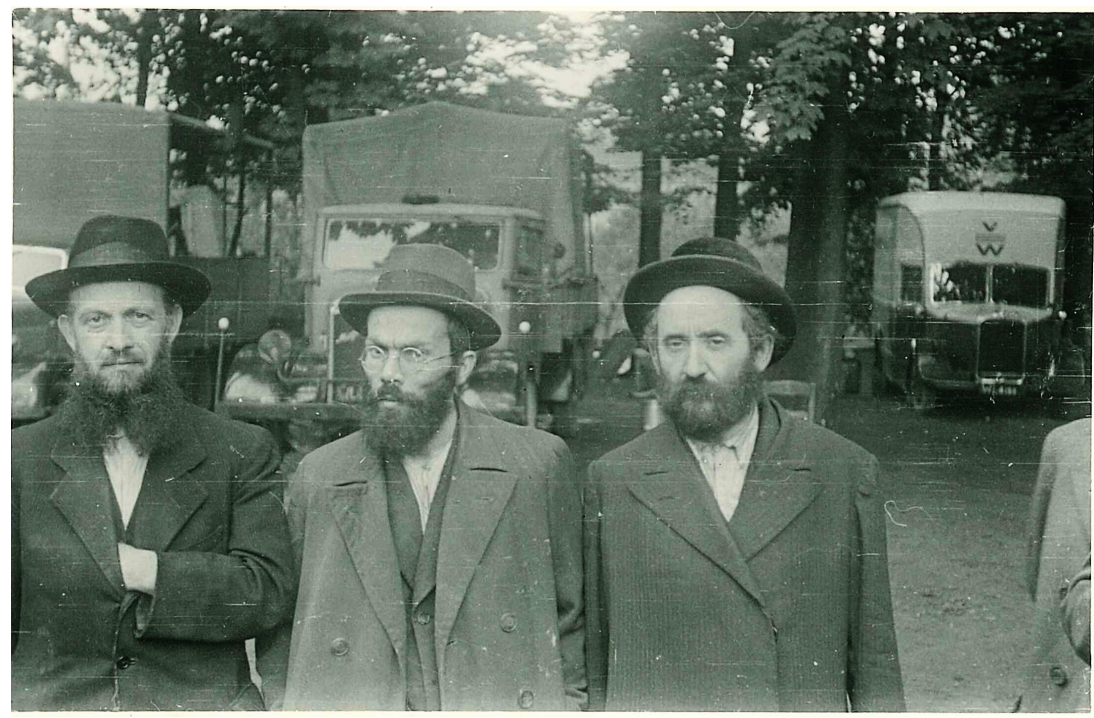

Krakow Jews, 1939

The first image depicts three Jewish males who appear reluctant to have their photo taken. Behind them are parked German military vehicles. Their faces 
show a mixture of irritation and confusion, and not one of the men looks pleased. Handwritten on the back in German is "Krakow, 1939." This photograph reminds me-not only in its subject matter and mode of production and gaze, but in the feeling it generates_of images found in the SS Auschwitz album, in which imprisoned women and men are forced to look into the lens of a camera held by an SS officer. Similarly, there is a resemblance to that iconic image of the boy with raised arms whose family is being evicted from the Warsaw Ghetto, a photo discussed at length by, among others, Hirsch and Susan Sontag. The photo is also reminiscent of Walter Genewien's collection of images that he took as a "tourist" of the Warsaw Ghetto while a member of Germany's Wehrmacht. In these types of photos a sense of resigned reluctance pervades, sometimes mixed with a streak of anger and often disbelief (or annoyance), notable in facial expressions or body language. In all cases, the subjects are required - it would seem - to look into the camera and not into the distance, or elsewhere. Alternatively, they are viewed from a distance as one might look at zoo animals, people captured both literally and figuratively for the pleasure of the photographer. They are, as Hirsch signals, photos of people shot on camera not long before being shot with bullets. ${ }^{1}$

The second photograph shows eight members of the SS Totenkopf-the SS branch that worked in the camps-at Mauthausen concentration camp. The men who committed crimes such as the gassings are having their picture taken by another perpetrator, or with a timer, or by an inmate. Such images are rare; there are limited records showing the men who were not high up in the SS hierarchy, but who carried out the crimes. A plethora of photos exists of Heinrich Himmler and Rudolf Hess for example, a small number of Josef Mengele, but very few of SS minions directly operating the killing machine. Here we witness men who are physical and masculine in some ways, yet verge on the bland, even the ugly. They are middle-aged and of middling weight. Their uniforms are loose, hair unkempt, their postures relaxed. In this depiction of uniformed mundanity, it is possible to infer the presence of families, the routine of work, and an aura of camaraderie. Somewhat ironically, while their physicality (or lack thereof) provides an antithetical redressing of SS mythology, these men are literally the overseers of life and death. These are the men responsible for keeping order in Germany's concentration camps in both a bureaucratic and physical sense, overseeing underling Trawniki guards, administering punishment, helping with selections, and carrying out gassings, shootings and hangings.

1 Marianne Hirsch, The Generation of Postmemory: Writing and Visual Culture After the Holocaust (New York: Columbia University Press, 2012), 13. 


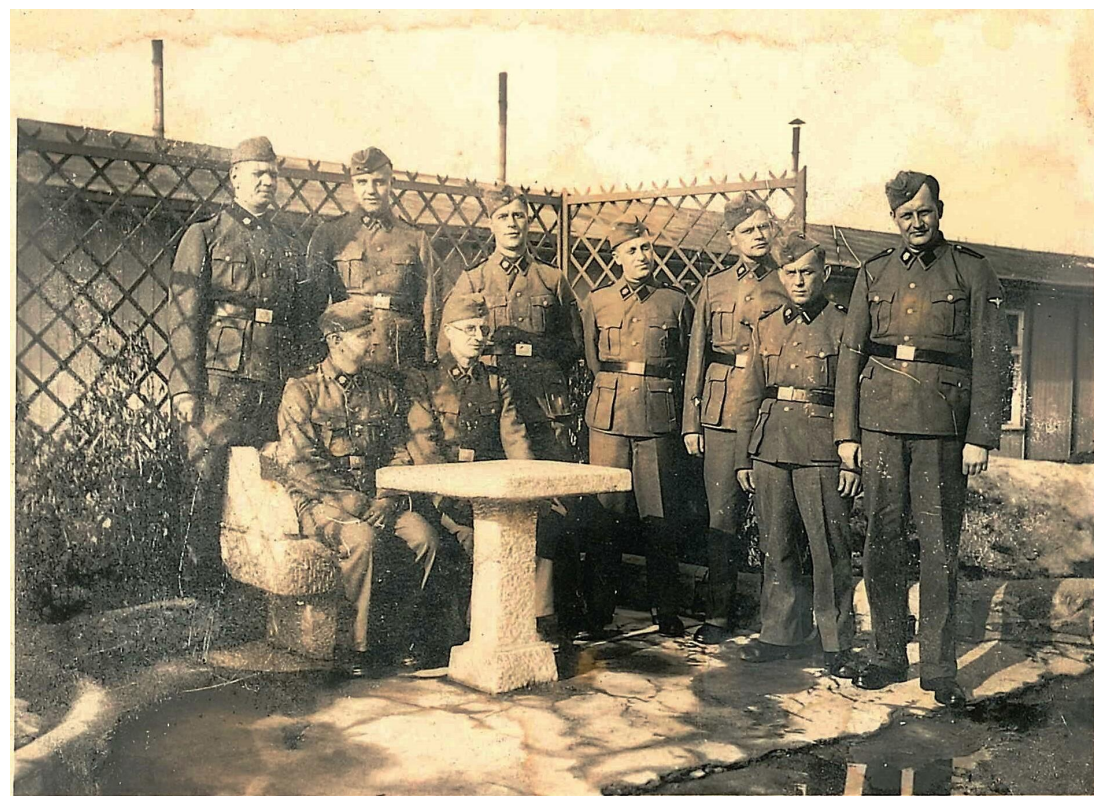

SS Totenkopf Guards, 1940s

Both photos either explicitly show, or allude to, the Holocaust, displaying literal and/or connotative connections to aspects of that past. "Literal" in that each photo, as John Frohmayer suggests, presents the viewer with evidence of the Holocaust, the irrefutable acknowledgement that such events took place. ${ }^{2}$ Photos such as these remove "doubt . . . they affirm 'having-been-there' of the victim and the victimizer, of the horror."3 Each photo, therefore, becomes a small piece of a larger historical narrative. Similarly, there is a semiotic connection to this past, each photo symbolic of a wider narrative, and each contains multiple signifiers to substantiate this broader history, though such readings are somewhat dependent upon prior knowledge. For example, in photo two, the men stand around a table and a bench carved from stone taken from the quarry at Mauthausen; the photo confirms the presence of the quarry and its infamous "stairs of death," a long stairway prisoners climbed while carrying heavy stone blocks. The table and chair come to represent the oppression of the Nazi slave labour camp system.

The photographers were most likely members of the SS who have taken

2 Cited in Marianne Hirsch, Family Frames: Photography, Narrative, and Postmemory (Massachusetts: Harvard University Press, 1997), 24.

3 Hirsch, Family Frames, 24. 
these as mementos, capturing moments of comradeship and the subjugation of others. The gaze (the photographer's viewpoint) is purposefully informative. Each has a certain wish, an ideology embedded within it; the Totenkopf men evidently wish to "put their hearts on their sleeve" for an ideology is marked literally on their uniforms, in the patches on their collars, their belt buckles, the caps, and the iconic death's head emblem. This and the way they hold themselves, and their lack of a smile, show a group of men intent on fulfilling political and gendered roles that, given the signs inscribed in the photo, require a balance of seriousness and mateship. In the photo of the Jewish men, it is the ideologue's viewpoint that positions their victims. German politics becomes evident for there is a clear divide, an "us" versus "them" distinction. This photo, taken by a Nazi, captures the captured (and makes evident the societal position of slave as compared to victor). Claude Lanzmann believes images like these deprive the viewer of anything outside of the Nazi gaze and are therefore problematic, as the perpetrator's intentions guide the onlooker. ${ }^{4}$ Similarly, Ulrich Baer suggests that Nazi images rob their Jewish subject matter "of any interior life and self-directed means of expression, while the Nazi photographer is endowed by historians with motives, feelings, and a rationale for his actions." These photos record "nothing but the 'ruination' and death of the Jews ... while they reveal a complex 'mental' stance and even the overall 'existential attitude' of the German behind the camera."' Agency becomes the privilege of the German, not the victim, and a viewer's reaction might be empathic to the victimised yet more understanding of the subjugator; action might be more easily conceptualised and understood than subordination. In the photo of the Totenkopf group, the image may negate this appropriation of agency, for the men are too average, too normal to determine people's fate, an ordinariness suggesting these men are not the masters of their own fate; they are merely the ciphers of a hierarchical ideology.

In both cases, the images convey a distinct message, one that privileges the German over the victim. The Germans as conquerors wanted to record their success. Those persecuted had little desire to remember the humiliation, other than to document atrocities for future generations. As losers in this battle, those imprisoned in the German photos are often positioned to feel like oddities, and their expressions reveal as much. To add to this visual bias, the Germans had affordable technology and many owned a small camera, so the

4 Ulrich Baer, Spectral Evidence: The Photography of Trauma (Cambridge, MA: MIT University Press, 2002), 138.

5 Ibid., 136.

6 Ibid. 
bulk of amateur photos of the period situate the victim politically and ideologically as the "Other." A contemporary viewer, therefore, imagines 1930s and 1940s Europe from the viewpoint of the Germans, or the Germans' accomplices, and it is only once the Russians begin incursions into former occupied Europe in 1943, followed by the Americans and British in late 1944, that the tone of the amateur photo differs. German photos are bestowed a sense of authority, and yet these images are unjust and unethical: mass-produced death, either literally or through association, is documented with some glee and admiration or, at best, with a level of curiosity.

\section{Historical veracity}

When discussing photos as individual snapshots of a time and place, the audience glimpses the past through a small and specific window that does speak to a larger narrative, but homes in on the specificities of the photo itself. The abundance of amateur photos, however, suggests a collective means of seeing this past, a cohort of images building a common remembrance. In both cases the contemporary viewer is, in the words of Gary Weissman, a "non-witness," as we have no first-hand knowledge of events. ${ }^{7}$ We are at an historic, cultural and temporal remove, and our role in these photos is more voyeur than participant. We are the non-witness to another's victimisation and torment. Sontag notes that "torment, a canonical subject in art . . . is often represented . . . as a spectacle, something being watched (or ignored) by other people. The implication here is: no, it cannot be stopped-and the mingling of inattentive with attentive onlookers underscores this." ${ }^{8}$ The nature of the amateur German photo suggests we remain voyeurs, watching from an advantaged dislocation, peering at images that are (consciously or not), boastful. Unlike photos that might catch a unique situation, a "one-off” occurrence, the prevalence of German amateur photos reiterates the fact that a victim's torment is not halted post-photo; rather, it continues, and we as spectators become witness to a photographer's ongoing political and ideological habits. We see his world the way he wishes us to see it. We see the world the way Germany, at that point in history, wished us to see it.

Amateur photography was a very much accepted and encouraged practice throughout the Reich. Rolf Sachsse notes in his study of Nazi photography that "[t]he power of the state rested not so much on the contribution of grand

7 Gary Weissman, Fantasies of Witnessing: Postwar Efforts to Experience the Holocaust (Ithaca: Cornell University Press, 2004), 18.

8 Susan Sontag, Regarding the Pain of Others (London: Penguin Books, 2003), 38. 
visual images provided by professionals, artists and photo-journalists, as on the simple praxis of shooting photos by anybody who could hold a camera in his or her hand." The everyday photographer, invited by the state, contributed to the nation's collective identity, and the every-persons' photo acted as propaganda. Aleida Assmann writes that, "the new decentralized medium of photography, which was put into the hands of the citizens to coproduce and maintain a shared collective memory, was central here." ${ }^{10}$ She continues: "The project of the NS State ... was to transform, as far as possible, external propaganda into personal practice, choice and habit. Together with the mass distribution of new private cameras, a visual regime was constructed and implanted into the minds of the citizens who then collectively practiced, shared and consolidated the iconic photos of the NS state themselves." ${ }^{11}$ Nazi amateur photos have an agenda embedded in them, not solely contrived by the individual, but sponsored by the government. They build a certain type of Germany akin to propaganda posters or Nazi movies. Individual photos become political messages, and while such images contain the normal and banal of the everyday-alongside battle scenes and comrades in arms - the collective effect intends to support and uphold Nazi ideology.

This becomes problematic when generations removed peer proudly through family albums, or when amateur German photos gain status as historical records. The emphasis shifts from the Holocaust per se, to the Reich more generally, possibly dissipating the importance of the Holocaust. Similarly, amateur photos present alternatives to those known as iconic of, and synonymous with, the Holocaust-images brutal in their content, such as the Jewish man kneeling on the edge of a pit awaiting execution. Iconic images, while often horrific, have become, some contend, too commonplace. Their presence on book covers, for example, at museums, or on television shows, dissipates their authority and their shock value. Caroline Dean, in her examination on empathy after the Holocaust, notes that, "assertions that we are numb and indifferent to suffering, that exposure to narratives and images of suffering has generated new and dramatic forms of emotional distance ... are by now commonplace in both the United States and western Europe."12 Alternative records such as amateur photos, therefore, might replace the iconic and over-used. Regardless of an interred bias, they offer a

9 Rolf Sachsse, Die Erziehung zum Wegsehen: Fotografie im NS-Staat (Dresden: Philo Fine Arts, 2003), 133.

10 Aleida Assmann, "Look Away in Nazi Germany," in Empathy and its Limits, eds. Aleida Assmann and Ines Detmers (London: Palgrave Macmillan, 2016), 132-33.

11 Ibid., 133.

12 Caroline Dean, The Fragility of Empathy After the Holocaust (Ithaca: Cornell University Press, 2004),

2 . 
new perspective, no matter how mundane, for each photo is authentic and documents a specific moment in time, attesting to what Roland Barthes observed in Camera Lucida, that photos adhere to the embedded referent and "can never deny the thing has been there [documenting] . . . absolutely, irrefutable [the] present."13 In their discussion of street scene photos of European Jewish populations, Hirsch and Leo Spitzer note that images of the period hold documentary value. ${ }^{14}$ Such photos-including those featured in this essay-contain historical veracity, and are first-hand evidence of what occurred. The photos discussed by Hirsch and Spitzer, for example, construct "an authoritative historical archive while also hoping to reactivate and re-embody it as memory."15 These are images of a Jewish population taken by street photographers. Therefore, their use to reactivate or invigorate a past needs certain considerations, but different considerations to those arising when dealing with the German gaze. Especially when, as noted, this gaze was purposeful propaganda attempting to build a National Socialist Europe.

\section{The return of the German gaze}

When Hirsch discusses the notion of postmemory, she is suggesting on the one hand that "memory can be transmitted to those who were not actually there to live an event," specifically children whose parents survived the Holocaust. ${ }^{16}$ She is also discussing intergenerational transference of memory through "the aesthetics of remembrance in the aftermath of catastrophe.” ${ }^{\prime 1}$ Hirsch writes that "postmemory's connection to the past is not actually mediated by recall but by imaginative investment, projection, and creation,"18 which is, when considering victim narratives and perspectives, an approach to this past that might have its concerns, yet remains morally tenacious if viewed from the vantage point of the victim. What if this production of memory, individually and more widely generated, derived from photos akin to those shown here? How might individuals or communities inherit these images if they become accessible historical documents? Similarly, how might a museum curate such images? Susan Crane contends that, "the normalcy of understanding, facili-

13 Roland Barthes, Camera Lucida: Reflections on Photography, trans. Richard Howard (New York: Hill and Wang/The Noonday Press, 1981), 76-77.

14 Marianne Hirsch and Leo Spitzer, “Incongruous Images: 'Before, During, and After' the Holocaust,” History and Theory: Studies in the History of Philosophy 48 (2009), 9.

15 Ibid., 14.

16 Hirsch, Generation of Postmemory, 105-06.

17 Ibid., 104.

18 Ibid., 106-07. 
tated through communication, as well as collective memory, is threatened by atrocity images. The 'universal language' theory would hold that any human eye will register the same content in any image, and thus replicate the intention of the photographer." ${ }^{19}$ According to Crane, therefore, images taken by perpetrators hold a certain power, and by their very vantage point, viewers are imbued with the photographer's perspective.

One way of negating the potency of such photos lies in the importance placed on them as historical records. Similarly, the importance attached to them as cultural artefact - deny the photos moral legitimacy through education and negate the risk of them becoming normalised and accepted viewpoints. There is also the assumption of knowledge a viewer brings to these images, realising something of this past and positioning these images accordingly, thereby neutering their potency as Nazi propaganda. In their exploration of Jewish photos of the past, Hirsch and Spitzer write:

Not only may these viewers be able to contextualize the images historically, inserting them within the broader tapestry of cultural/collective or personal/ familial resemblance, but they also bring to them an awareness of future history - of events-yet-to-come that could not have been known to the subjects of the photographs of their photographers at the time when the photos were taken. ${ }^{20}$

While aspects of this statement might not relate to the photos examined here-in that events-yet-to-come were seemingly known or predicted by the Nazi photographer, for the Germans would win!, would be victorious!- - the idea that contemporary audiences contextualise images with this history in mind remains applicable. Audience knowledge, the building of such knowledge, and curatorial positioning that adds to knowledge, are important tools in the negotiation of amateur German photos. In the case of the two photos here, however, pragmatic suggestions present their own concerns, presupposing as they do that the viewer has sufficient knowledge of the Holocaust, and that curatorial practices ensure Holocaust narratives are not pushed aside by alternate stories that question the historicity of the Holocaust. These presuppositions have proved less than dependable on occasions.

Alternatively, as Crane suggests in her paper "Choosing Not to Look: Representation, Repatriation, and Holocaust Atrocity Photography,” these photos

19 Susan Crane, “Choosing Not to Look: Representation, Repatriation, and Holocaust Atrocity Photography,” History and Theory: Studies in the Philosophy of History 47, no. 3 (2008), 311.

20 Hirsch and Spitzer, "Incongruous Images," 15. 
are possibly best removed from the public and "should perhaps fall under the same category as Nazi medical experiments: they have been rendered inadmissible because they are ethically compromised materials, made without the participants' consent." ${ }^{21}$ Whilst this idea is appealing at first blush, the vast number of German images circulating between private collectors on internet sites such as eBay and Gumtree undercut the proposal. Amateur German photos are accessible in bulk, taking up viewership on sites such as Instagram and Facebook. "Collection of wartime atrocity images and gruesome war trophies by combatants and civilians alike," noted Crane in 2008, "has become not typical, but also not unusual . . . [and] have dramatically increased with the advent of the Internet."22 Eight years has lapsed since Crane's observation, and technology has only heightened the accessibility of such German images. Instagram account "die_soldaten," for example, posts glorified images of the Wehrmacht and the SS and has almost 18 thousand followers. "germanmilitarypower" boasts over 30 thousand followers, and "the_wehrmacht_and_ss" over 10 thousand, and these sites, and many others, upload amateur and press photos taken from the German perspective on a daily basis. We return, therefore, to the overarching debate: how to deal with photos whose Nazi gaze proudly shows trauma inflicted on others, or makes banal and dull (or glorifies) the perpetrators and, by association, their crimes.

More theoretically, though not separate from educative and curatorial considerations, amateur German images invert what Barthes calls the punctum of the photo. In Mythologies, Barthes suggests the political photo "has the power to convert" and goes into some detail revealing how politicians assemble images to sell themselves, to convince an audience of aptness and show credentials. ${ }^{23}$ Photos examined here might be less overt than politicians' propaganda, yet work in similar fashion. We see the world as the photographer wishes us to see it: we look at a world through a specific set of German eyes that reveal a time and a place. In the case of both photos - and of photos of the genre more generally - the viewer projects into them what the photographer expects (or hopes); in this way the photo has a function, "to inform, to surprise, to cause to signify, to provoke desire." 24 The onlooker is educated by the photo and gets to know something about the educator. A triadic symbiotic relationship arises: the viewer learns about the subject matter, and, in doing so, comes to understand, in some measure, the photographer. In this case, the German 
gaze seeks to show the power relationship between Germans and the victim; in the process, without even seeing the person behind the camera, we gain insight into the photographer. We learn something about their gender, race, mindset, politics, hobbies and interests, profession, family life, their dress, what they eat and drink, and their dislikes.

Knowledge is literal and connotative: we can see these things and we can read into these images. Barthes goes on to highlight aspects of the photograph that he calls the studium by introducing the notion of the punctum, those moments in the photo that "shoot out of it like an arrow, and pierces me. . . . A photograph's punctum is that accident which pricks me (but also bruises me, is poignant to me)." ${ }^{25}$ When Hirsch and Spritzer discuss photos taken of a Jewish population walking in pairs or in small groups down a street in an Eastern European city, the punctum is that moment that arrests your gaze and your imagination. In these photos of European Jewry, this moment might be the yellow star pinned to the clothing. The viewer is "pierced" by a small detail that "annihilates the rest of the image"26: the abnormal in an otherwise normal scene. The punctum, writes Barthes, "changes my reading, that I am looking at a new photograph, marked in my eyes with a higher value."27 The street photo conveys, on an initial viewing, two or three people from a certain period enjoying a day out. At that moment of piercing, when we spy the yellow star, the photo invokes another narrative, one that undermines and revises initial readings.

If we look to the two photos in this study, there are moments in either that indicate this punctum, such as the SS uniform, and yet the punctum is not what is shown, but what is not shown. The photos' secondary narrative, their encoded meaning, destroys the innocence or normalcy of the images. The photo tells, without literally showing, that death awaits the Jewish men, or that these SS men are the killers. Such images invert Barthes' concept of the punctum for they reveal the photos' hidden intentions; agendas pushed just out of view of the audience. For an onlooker to decipher these encoded messages, the punctum needs to be there, somewhere. To the unfamiliar, the men in uniform are just men in uniform in an old photo, and while some may gawp over the fact that these individuals are part of the infamous SS, there is little to signal their actual roles. Similarly, while the photo of the Jewish men reveals the Holocaust, the true situation lies just beyond the frame of the photo itself. So there is a need to negate the image as seen at face value, otherwise misread- 
ing occurs. The punctum needs to deflate the nefarious gaze that privileges the German. Similarly, a certain embedded pathos is present in these photos, one not necessarily accentuated by the visible content. Sympathy should be extracted rather than nationalistic pride, but this is not so easy without that punctum. Crane argues that, "with atrocity images, we have tended toward preservation as if by moral imperative, but if that choice means retention of, and indeed conservation of, the Nazi gaze, we should consider the alternatives. ${ }^{28}$ The inclusion of the punctum allows for a more nuanced and ethical positioning, less binary in its approach to Nazi images than noted in Crane's suggestion, and provides a more general audience, those without the scholarly background, the encoded knowledge that bruises, internally ruptures, and pierces. The alternative to this punctum, Crane argues, is to "choose not to look" or to choose on behalf of onlookers the photos they should or should not view, ${ }^{29}$ an idea undermined by the multitudinous amateur Nazi photos already present in the public domain.

The insertion of a punctum, a moment of acknowledgement that annihilates what comes before, serves two purposes. First, it draws an audience to the image, since surface level readings only attract a certain degree of interest. Second, the photo is contextualised, made to fit within the wider context of the Holocaust, thus providing a modern audience with an "honest" reading. Deny the photos their place in the Holocaust and take them solely to show Jewish men or men in uniform, and the true atrocity of what they represent stays hidden. This attempt to quash a viewer's initial experience would therefore negate some of the Nazi gaze when this gaze does not show the atrocity first-hand. What, though, of those many hundreds of thousands of photos not directly tied to the horrors, to the atrocities of the Nazi regime, yet are part of this "everyday" propaganda machine? What about those vernacular photos that show Nazi life?

\section{Cultural memory and sympathy}

The risk in providing amateur German photos currency as historical documentation is that they legitimate the Nazi perspective. "Legitimate" in that the emphasis currently placed on the Holocaust becomes sidelined, not consciously (though conscious decisions still antagonise in the form of Holocaust denial, for example), but because of an ulterior narrative. In the more banal photos of Nazi life, day-to-day existence is pleasurable and seemingly whole-

28 Crane, “Choosing Not to Look,” 322.

29 Ibid. 
some. There is, as mentioned before, nothing innocuous about these narratives, aside from their place in time and history as seen retrospectively. Revisionist narratives about the Holocaust have already emerged in other artistic and aesthetic endeavours, such as the genre of fiction, in book form, including The Hand that Signed the Paper. ${ }^{30}$ In Helen Demidenko/Darville's novel, Ukrainian history is rewritten to privilege a Ukrainian family who work in, or marry members of, the SS. Originally touted as semi-biographical and told from the perspective of the Australian/Ukrainian granddaughter of these former SS, the writer eventually revealed she was British in heritage with no connection to this past whatsoever. By then the book had won two prestigious Australian literary awards and had sold multitudes of copies. With amateur photos, we could be seeing a similar movement in the popularity of internet realms that privilege a German gaze. Given the numerous amateur German photos for sale on the internet or in antique shops - due, possibly, to the death of family members whose possessions are not wanted-the social and cultural repercussions are multifaceted and complex. For example, what were once private photos are now in the public domain, which sanitises the true story behind the photo, while those who bore witness to the atrocities, whether victim or perpetrator, are no longer alive to provide context. Generational memory is shifting, and with it cultural and societal attitudes.

Associated with this trans-generational transmission is an assumption, writes Sontag, that the photo, in contrast to the painting or the novel (for example), intends to show and not evoke, suggesting objectivity. Photos are believed to be real-life moments that bear witness and are therefore "true." The audience might react with interest, but with a limited ability to decipher bias and subjectivity. ${ }^{31}$ We have inured within us the belief that photos are factual representations of life moments that tend to contain fewer, if any, insinuations, especially if images are at a remove from politics and the press. Vernacular photos such as family holiday snaps, individual portraits, school mementos, photos of picnics and weddings are seemingly no place for politics. This attitude is coupled with the problem of temporal distance. We therefore, supposedly, do not question a photograph's intentions. Similarly, the distance between now and the event itself further lessens a photo's impact on contemporary psyches. And there has been, interestingly, mixed reaction from scholars regarding the potency of amateur Nazi images on a contemporary audience.

Exploring the divide between present and past in her discussion of post- 
Holocaust empathy, Dean suggests that distance might lead "to insufficient or disingenuous sympathy" by later generations. ${ }^{32}$ Both Dean and Dominik LaCapra, among others, explore the notion of empathy post- Auschwitz and find the notion tenuous, yet for differing reasons. LaCapra writes that "empathy itself, as an imaginative component not only of the historian's craft but of any responsive approach to the past or the other, raises knotty perplexities, for it is difficult to see how one may be empathetic without intrusively arrogating to oneself the victim's experience or undergoing (whether consciously or unconsciously) surrogate victimage." 33 Here LaCapra suggests Nazi photos do privilege the victim, and yet the audience may adopt a position of "surrogate" victimisation, a somewhat nihilistic approach to another's suffering. Assmann notes a divergent stance in some approaches to Nazi images, suggesting photos of victims-including the trains and the camps-initially tokens of Nazi superiority, now evoke an antithetical and appropriate emotional response. She contends that "the same photos that had been taken in a state of utter lack of empathy with the victims [pre-1945] were suddenly charged [post-1945] with enormous empathy with the victims." ${ }^{34}$ New generations who look at iconic Nazi photos or artwork in which Nazi images are incorporated, and see victimisation over perpetration, often reinvigorate sympathy for the victim, Assmann notes.

Conversely, Caroline Dean questions the role of Nazi photos and our modern-day social conscience, and though she looks specifically at photos of atrocity, one of the questions raised is pertinent when discussing "banal" Nazi images: do Nazi photos excite or numb us? ${ }^{35}$ In answering this question, Dean looks to a gap identified by a group of "heterogeneous scholars" that separates "representation from responsibility ... between emotional allegiance to empathy and a sense that this term [empathy] can no longer capture modern historical experience." ${ }^{36}$ Dean examines three terms she believes question the legitimacy of empathy in contemporary Western society, and all three are products of post-Holocaust generations. She suggests that "expectancy, excitement, voyeurism . . . violate the dignity of memory by taking the historical event out of context, by appropriating it for our own pleasure and rendering meaningful empathy impossible." ${ }^{37}$ While Dean looks at contemporary

Dean, Fragility, 3.

33 Dominik LaCapra, History and Memory after Auschwitz (Ithaca: Cornell University Press, 1988), 182.

34 Assmann, “Look Away,” 136.

35 Dean, Fragility, 6.

36 Ibid., 7.

37 Ibid., 24. 
artwork as a case study, and refers to processes of historiography more generally, these three ingredients are potentially implicit in the photos featured here. To collect these images and to post them on social media is an example of appropriation, for in either case there is some degree of nihilism and self-pleasure. There is something politically wilful in the reappropriation of amateur Nazi photos, and this approach mimics, to a degree, the initial intentions of the photographer. Furthermore, collecting Nazi photos can become a hobby that seemingly ignores peoples' fates. If fate were a consideration, some reference to the Holocaust, rather than none, might accompany amateur German photos found on numerous Instagram accounts. It might also be the case that, as we play a voyeuristic role, and knowing something of the Holocaust more generally, there remains a certain expectation placed on these photos: a contemporary audience expects a certain type of narrative rather than the historical narrative. These images, for example, excite by emphasising uniform over civilian or machinery over humanity, the battle rather than the casualties. Similarly, they highlight the "Germanic type" who dominates "Others." Expectancy, excitement and a voyeuristic element are not the products of a less than sympathetic contemporary audience, but the products of modern society more generally. James Dawes, in his publication Evil Men, argues that "empathy and the altruism effect ... can be contingent on social constructs, artefacts of a particular society's way of socializing its subjects into collaborative prosocial behaviour, and they can nonetheless still feel as implacable as biology in shaping the lives of those subjects." ${ }^{38}$ Empathy, according to Dawes, does not come naturally, and social conditioning establishes the preconditions for sympathetic outcomes or reactions.

Originally taken as a somewhat less blatant form of propaganda, Nazi amateur photos become historical artefacts in a global society where empathy is forced or false, and sympathy for those victimised might already be under stress. This poses a danger to the collective memory of the Holocaust or, at the very least, a problematic combination. Sontag believes that "remembering is an ethical act, has ethical value in and of itself. Memory is, achingly, the only relation we can have with the dead." ${ }^{39}$ Similarly, Assmann writes that blocked empathy leads to blocked memory. ${ }^{40}$ Given the photo's original intention, sympathy remains stalled and empathy becomes something of a hollow reaction, as the photographer's prerogative was neither. If sympathy/empathy were unintended, then the memorialisation of the victims might be altogether 
negated. It could be difficult to inspire sympathy, much less empathy, when a contemporary reading of such images defers to the original gaze. Amateur German photos are not going to evoke large-scale emotional reaction that privileges the victim, as this was never their intention. Their pathos accentuates the victor: jubilation rather than humiliation, and so forth. What such images might do in their quantity and gaze is to remove an emotional reaction for the victim, and instead fascinate over the perpetrator. As Hirsch and Spitzer note, the incongruity of retrospectively adopting old photographs, "tell[s] us more about what we want and need from the past, than the past itself." 41 Here we might be witness to the onset of a new generation of memorialisation, helped by the Nazi photo that adds to current knowledge, but from a perspective with a dubious moral and ethical content. Oddly, the very thing these photos meant to do some years ago, might now be acting out.

\section{Conclusion}

While the normalising of the Nazi gaze seems a bleak forecast, amateur photos of the Reich do offer some alternate readings of this past, allowing further insight and investigation. They do show the history in a broader context and in highlighting atrocity there is always a victim: there cannot be one without the other. Amateur German images, therefore, are not without their reference to those victimised even if they never intended these photos to signal victimisation. The two photos used as case studies are, I believe, apt but somewhat extreme examples of the types of photography the Germans took with their small cameras. They show the murdered and the murderers, whereas most photos are content with day-to-day generalities. Vernacular showings of life in the Reich, though, are most potent when normalising the German viewpoint. The Holocaust is no longer a central feature, neither is war nor the carnage of battle. These amateur photos lack the punctum, and even locating them within the historical narrative of the time does little to provide the moment that "annihilates" the image. The two photos cited literally and figuratively refer to the Holocaust, and alongside those found in the Auschwitz album for example, they have a kinship to iconic images used to evoke post-Holocaust empathy. Ironically, the more macabre and telling of disaster, or the more iconic an image becomes - the more powerful the punctum - the more sympathy might be extracted from post-generations. Countless other photos, used as Nazi propaganda, though relatively boring in their content, show life under National Socialism to be convivial, healthy, productive and, even in times of war, rela-

41 Hirsch and Spitzer, “Incongruous Images,” 23. 
tively pleasant. These images are the more acceptable, for in them death is not apparent, nor is killing. They build an overall oeuvre that privileges normalcy over the macabre or iconic, but they do not call on an individual's imagination. They are possibly too dull for the modern audience, too normal for them to be of interest. And possibly this normality becomes their undoing as historical reference; cultural reappropriation and trans-generational shifts are less likely the outcome of the mundane. Similarly, though somewhat contradictory to this lack of excitement, amateur German photos fit within what Inga Clendinnen calls a strange opposition in relation to the Holocaust, a continuum "which begins with the familiar and extends to the profoundly strange."42 This disparity is particularly true of images revealing everyday machinations of the Reich. Because, by their very historicity, their setting and subject matter (their Third Reich vernacularity), these photos are beyond a contemporary viewer's comprehension. That may be, among other factors, the strongest antidote to their potency. And yet while they show day-to-day life of the Third Reich, this in itself reveals a lack of normalcy, for life under Hitler's reign must have been anything but normal. 